\title{
Development at the Margins: Livelihood and Sustainability of Communities at Malaysia - Indonesia Borders
}

\section{Junaenah Sulehan}

Faculty of Social Sciences and Humanities; Center for Social, Development and Environmental Studies; University Kebangsaan; Malaysia e-mail:june@ukm.my

\section{Noor Rahamah Abu Bakar}

Faculty of Social Sciences and Humanities; Center for Social, Development and Environmental Studies; University Kebangsaan; Malaysia e-mail: rahamah@ukm.my

\section{Abd Hair Awang* *}

Faculty of Social Sciences and Humanities; Center for Social, Development and Environmental Studies; University Kebangsaan; Malaysia e-mail: hair@ukm.my

\section{Mohd Yusof Abdullah}

Faculty of Social Sciences and Humanities, Center for Media and Communication Studies, University Kebangsaan, Malaysia

e-mail:myusof@ukm.my

\section{Ong Puay Liu}

Institute of Ethnic Studies, University Kebangsaan, Malaysia e-mail:puayliu@yahoo.com

ABSTRACT Small communities living on the margin of development generally face a myriad of issues and challenges. Paradoxically, although livelihood is a major concern for these communities, their integration into the mainstream of development seems a remote and endless problem. This article, therefore, has three objectives. Firstly, it discusses the socio-economic dynamics of the Sarawak-Kalimantan border communities whose villages are obscured from the mainstream of development. Lately, villages and small townships along this border had caught the attention of the media,

\footnotetext{
**: Corresponding author
} 
politicians, planners and researchers. This was the consequent result of media highlights on Malaysia-Indonesia border disputes and cultural issues, which were further expanded to encompass matters relating to national security and economic interests of both countries. However, the socio-economic plights of these border communities were seldom articulated. Secondly, based on case studies conducted between 2009 and 2010, this paper focuses on issues of livelihood and sustainability of these border communities, particularly the Bidayuh ethnic living in Serikin (Sarawak) and JagoiBabang (West Kalimantan). The studies especially focused on the participation of these villagers in the socio-economic spheres within the border areas, and also assessed to what extent the livelihoods of these villagers were influenced and affected by such dynamics. Lastly, by exploring the possible theoretical explanation of the unique social phenomenon taking place at the margin of development in Malaysia, this article examines the embedded cultural and social affiliations which help sustain the tradition of economic exchange between communities on both sides of the borders.

Key words: community development, livelihood, sustainability, border communities, social dynamics.

\section{Introduction}

The predicament of border communities in Malaysia, including issues pertaining to their economic livelihood, social vulnerability, security, ethnic relations, environment and sustainability, are seldom highlighted. This causes small communities living on the fringes of the Malaysia-Indonesia border in the Sarawak-Kalimantan region, face myriad of issues, become socially as well as politically vulnerable, and make their integration into the mainstream of development seems remote. Ironically, their plight was raised in endless debates only when border conflicts between Malaysia and Indonesia occurred or when security matters affecting both countries became open issues. The realities at the Sarawak-Kalimantan border, however, are least affected by the media debates concerning those bilateral issues. In this region, the territorial delineation between the two countries has never been perceived as barrier to the free movement of people and goods. The border has become a venue where various interest and actors play out their roles (Koji, 2003). In fact a large number of the communities on both sides of the border share common ethnic, linguistic and cultural identities, traits which have existed and practiced even before James Brooke came on the soils of Borneo (Crain, 1994; Bala, 2002). These common identities had thus been used by the communities from both sides of the borders to often seek ways to maximize employment, trade and social opportune in particular into Sarawak territories (Junaenah Sulehan et. al, 2008).

This article has three objectives. Firstly, it discusses the socio-economic dynamics of villages on the Borneo Border of Sarawak-West Kalimantan. Secondly, based on case studies conducted between 2007 and 2009, this article highlights the livelihood and sustainability of the Bidayuh ethnic living in Serikin (Sarawak) and Jagoi Babang (West Kalimantan). This is done by assessing their participation in the socioeconomic spheres and ascertaining to what extent their livelihood is influenced and affected by the border dynamics. Finally, by exploring possible theoretical explana- 
tion to the unique social phenomenon taking place at the margins of development in Malaysia and Indonesia, this article examines how far the embedded cultural elements and market dynamics are able to sustain the social affiliation and traditional economic exchange of the communities on both sides of the borders.

Serikin is a small, remote border town, but is busy on the weekends for informal cross border trades. The town is located about 5 kilometers from the border of West Kalimantan, Indonesia (Map 1). The majority of the community living in Serikin is the Bidayuh community, an ethnic group categorized under the Dayak group living in rural areas. This town has a small immigration post, custom office, police station, and a military camp to ensure territorial sovereignty and the illegal activities mainly human and commodities trafficking are under control. Most of the border communities used trails or "mouse paths" (jalan tikus) for cross-border workers, trading (smuggling) various commodities and visiting relations. These movements occur without valid passes which the local communities regarded as the traditional routes.

Map 1

Borneo and Serikin (Sarawak)

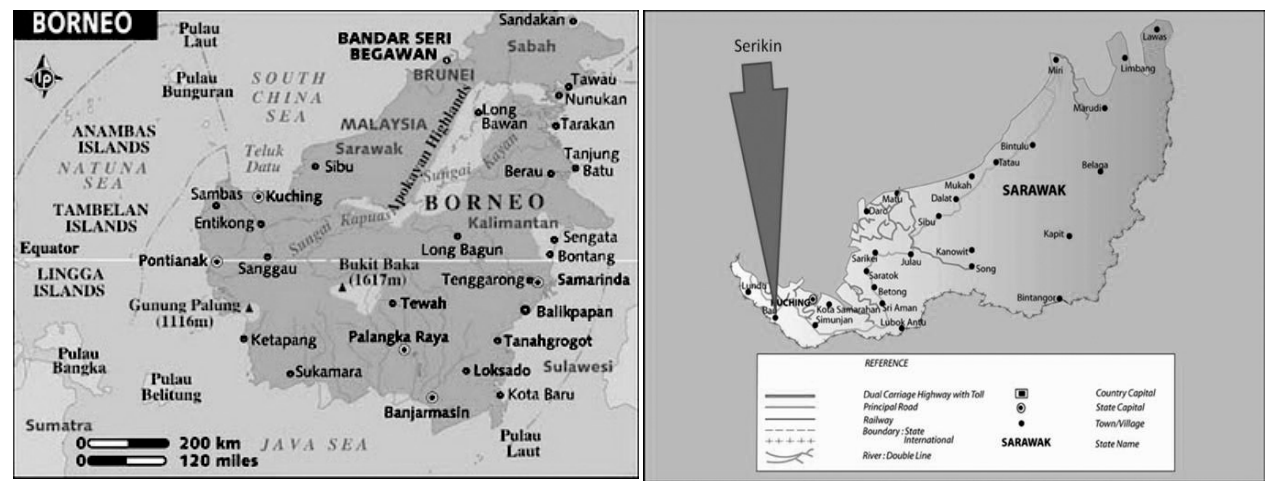

\section{Communities: socio-economic dynamics}

Villages located along the Sarawak-Kalimantan borders have always been obscured due to their geographical remoteness and limited access to development facilities and amenities. Of late, however, villages and small townships along this border had caught the attention of the media, politicians, planners and researchers. This was the consequent result of media highlights on Malaysia-Indonesia border disputes and cultural issues, which were further expanded to encompass matters relating to national security and economic interests of both countries. The geographical obscurity and the negative media highlights, however, do not alter the pleasant realities at the Sarawak-Kalimantan border. This is because Malaysia and Indonesia have a long history of social cordiality, and communities living at the edge of the Sarawak-Kalimantan borders have always cherished their common ancestral kinship affinities, religious practices, beliefs and traditional economic transaction (Ketut, Langub and Chew, 2004). These common legacies play a big role in the sustenance 
and continuity of relationship of the inter-border communities. Additionally, the porous Sarawak-Kalimantan border accentuates trans-border movements (Bariyah, Lau and Mansor, 2012), although mostly without valid passes and only using forest tracks, known as "jalan tikus" or the mouse path, which are regarded by the locals as the traditional routes before inter-border roads and linkages were built (Amster and Lindquist, 2005). This "jalan tikus" or illegal routes, is of course of convenience and an advantage for people wanting to seek employment, conducting cross-border trade, finding access to social facilities like clinics, schools or simply to visit their relatives on each side of the border. Undoubtedly, the regular use of this "jalan tikus"is becoming a very complex issue to the management of the Malaysia-Indonesia bilateral relations. Both countries are now attending to this issue with a distinct spirit of cooperation and cordiality.

The existence of such "jalan tikus" in the Sarawak-Kalimantan border, however, is of significance to this article. It manisfested that the creation of colonial borders over the past several hundred years and the subsequent partitioning of ethnic populations did not entail an end to migration and interaction between ethnically related communities now residing on each side of the borders. On the contrary, economic, social and political interactions have continued post-independence (Eilenberg and Wadley, 2009). Hence, even though Malaysia does not allow dual citizenship, it nevertheless puts in place some mechanism of control to facilitate orderly movement amongst people living at the border. This mechanism is also implicitly designed to curb illegal entry by Indonesians seeking employment in Malaysia. The Malaysian government thus provides temporary border passes valid within a certain limited duration to enable communities at the border to legally cross over within a specified limited period.

Following the 1967 Basic Agreement between Malaysia and Indonesia, therefore, it was decided that inhabitants living on either sides of the immediate Sarawak-Kalimantan border areas to be allowed to cross the border for short social visits (Eilenberg, 2012). The local communities in both countries along this border are able to trade for basic necessities. This permission, however, categorically prohibits the pass holders from seeking employment while on their social visits. To be able to do so, a Border Crossing Pass (Pas Lintas Batas) was needed, locally known as Surat Merah [Red Letter] (Eilenberg, 2009; 2012). The Pas Lintas Batas enables the Indonesians or Malaysians to cross the international border without the official passport to visit relatives within 5 kilometer from border areas. With this travel document, the border villagers are allowed entry either to Malaysia or Indonesia, but within a specified distance of $30 \mathrm{~km}$ within the border areas.

\section{Who are these border communities? - a conceptual discussion}

In most discourses on border communities, identity and ethnicity are two common aspects which characterized the inter-relations between the border communities and between the border communities and the state (Amster and Lindquist, 2005; Ishikawa, 2010; Ketut, Langub and Chew, 2004; Tirtosudarmo, 2006). Who are these 
border communities? The answer is not straightforward, especially when identities of border communities are usually associated with historical and kinship ties between the people separated by political boundary, rekindled and reinforced through regular border movements and economic exchanges across borders. The constant movement and interaction across the Borneo borders foster fluidity in identity, to the extent that the people have a layering of multiple identities which enable members of the different border communities to identify and relate to other sub-groups within their physical proximities. These identities are not static nor rigid, but interchangeable based on situation and importance. With the existence of border markets, and less stringent regulation on cross border movements, this community have the opportunity to be physically mobile, facilitating cross-border visits to family and kin. These frequent visits strengthened and fostered social cohesion (Yokoyama and Sakurai, 2006) among the communities across borders, especially when they shared familial ties and linguistic similarities. The sense of national belonging has a tendency to be fluid, particularly when the center of power is distant away from the border, and development programs and interventions for border communities are not always forthcoming.

Currently, although no concrete definition has been agreed upon, one general definitive conclusion has termed 'border' as a designated line of demarcation signifying the boundaries of power between two countries. It is a zone that invites or even entices people from both sides of the border to engage in activities that could be said to be legal or illicit, depending on the laws and regulations of the respective countries, and the social acceptance of the communities concerned.

Eilenberg (2009) writes that the West Kalimantan borderland has for long been a site of extreme anxiety for the modern Indonesian state, and the border population is often seen as precarious and potentially subversive subjects adhering to various illegal practices as part of their daily livelihoods. Eilenberg's research area is the remote border district of Kapuas Hulu, West Kalimantan, Indonesia, which has for centuries been engaged in undocumented labor migration across the porous border into Sarawak, Malaysia.

Conceptually, this article attempts to look at border as a social space and its cultural realm, transcending the geo-political definition of boundaries of sovereign states. The contention pertaining to issues of cross-border and border crossings are politically delicate, linking also to social cultural milieu of the affected communities between two countries. Communities sharing borders tend to recognize, identify, and share cross-border cultures, values, interaction and ideologies. These are pertinent elements in the social context, where social interaction of border communities are predominantly accentuated by historical and kinship ties and the mutual relationships based on the layering of multiple identities as explained earlier.

In 2002, the concept of borderland was widely used to discuss the filial connection of border communities in Southern Thailand and Northern part of the Malaysian border. This borderland is referred to as 'interstitial zone' which relates to area of 'displacement' and 'deterritorialization' to manifest the form of hybridized subjects 
in relation to border identities in the real sense and reject the essential definition of nation-state (Horstmann and Nishii, 2002). However, such construction of the 'interstitial zone' at the Serikin-Jagoi Babang border villages may not be applicable as the state of displacement does not take place, instead strong sense of belonging and recognition of cross-border identities of the ethnic sub-groups of the Bidayuh communities is imminent.

\section{Research methods}

\section{Selection of respondents}

The research team selected Serikin town as the research site. Serikin was chosen because it was one of the three important border town besides Tebedu and Entikong. Serikin is located at the fringe of the political boundary separating Malaysia and Indonesia. Serikin town has develop into a bustling border bazaar where majority of the traders come from Kalimantan and a handful from Sarawak. For data analysis, different sources of data collection were used. These include survey for the petty traders at the border market, focus group discussion, and in-depth interviews amongst selected village communities on Serikin side. With such methods, the research team could triangulate the collected information to minimize uncertainty and error (Gay and Airasian, 2000). A focus group discussion with the local communities was conducted specifically to gather the socio-economic and cultural consequences of development at the borderland. Thus provide authentic data based on their experienced and everyday lives (Cook and Crang, 1995). There are about 351 traders in Serikin town. The sample size was based on Krejcie and Morgan's (1970) (in Gay and Airasian, 2000) formula, whereby for a population size of 351 petty traders, the sample is 186 respondents. About 186 questionnaires were distributed and only 51 completed questionnaires were returned. This survey employed generic questionnaires aimed at obtaining respondents' personal experience in carrying out the business activities and their perception on the relationship with communities on the border of Serikin. Key informants mainly village leaders, old people and local trades were selected for the in-depth interviews aimed at capturing diverse range of opinions on business activities and opportunities, as well as on their perception of Indonesian traders and families who make weekly visit to this border village. Through open-ended questions of focus group discussions had helped verify information collected and provided additional relevant data to the studies.

\section{Result and discussion}

\section{Livelihood and sustainability}

A study of the communities, predominantly of Bidayuh ethnic origin (from both sides of the border villages in Serikin (Sarawak) and Jagoi Babang (Kalimantan), 
was conducted in 2009-2010. The Bidayuh, who make up over eight per cent of Sarawak's population, are believed to have been the first people to settle in the original territory of Sarawak acquired by James Brooke in the mid-19 $9^{\text {th }}$ century and were formerly known as Land Dayak (Leo Mario Noeb, 2006:88). Members of the communities from both sides of the border share common customs and traditions, beliefs, sustain kinship affiliation and maintain economic transaction manifested in the form of petty capitalism and barter exchanges. In terms of border surveillances, Serikin Village has an immigration post and other security presence such as a small custom office, police and a military camp to curb trans-border illegal movement of people and goods. Jagoi Babang, the border village at the West Kalimantan side serves as a transit point for communities from West Kalimantan who travel from their villages and towns into Serikin village. Transport from their respective villages stop at Jagoi Babang. After that, these villagers will continue their journey into Serikin by riding on rented motorbikes which can easily access and maneuver across the dusty and badly maintained feeder road.

Serikin, which is a tiny, rustic and remote village at the Sarawak border is going through socio-economic transformation ever since this village serves as an important business center since early 2000, taking over the once famous border trading center at Tebedu (border town in Sarawak territory), where the Checkpoint Immigration Quarantine (CIQ) is located. The Tebedu (Sarawak)-Entikong (West Kalimantan) border bazaar lies about one and half hours by car from Serikin. The migration of traders from their former trading bazaar at Tebedu-Entikong to Serikin was because of the Indonesian government's policy to shift their trading bazaar further into their side of the Entikong township. This shift had discouraged buyers from Sarawak to shop at the new trading premises because of the hassle to apply for passports and the new distance from the Sarawak CIQ. Tebedu, on the side of the Sarawak border, is the only checkpoint in Sarawak that requires the use of international passports. This factor had caused the growth of Serikin village, which develop into a bustling border bazaar with majority of its traders come from West Kalimantan.

The growth of Serikin as a bustling bazaar, thus encourage buying and selling, as well as promoting consumer tourism at the border. The case study conducted also considered Serikin as a cultural entity for maintaining traditional relations between families across borders of Malaysia and Indonesia. Serikin comes alive during the weekends, from Friday evening to Sunday afternoon, when petty traders from West Kalimantan make their way into this border bazaar to sell their products, together with their fellow Sarawak traders from Serikin, other neighbouring villages and small towns located close to the borders (the town of Bau, which is closer to the border and Tebedu, an hour and a half drive from Serikin). Traders from several small towns and villages of West Kalimantan will transit at Jagoi Babang, using their Border Pass, or Pas Lintas Batas, a document they must possess and live with, if they need to come into Serikin legally. Small makeshift stalls built of planks and recycled woods stood at every space available. Potential customers from far and near, within Sarawak, and tourists from Peninsular Malaysia, Brunei and Singapore make a beehive to Serikin during the weekends. Promotion of Serikin as a border bazaar are widely printed on tourist brochures. 
The weekly trading activities have carved a name for Serikin as a bustling weekend border town for buyers and sellers, for visitors and tourists, from within Sarawak itself, from other states of Malaysia and also from outside of Malaysia. Serikin is located $90 \mathrm{~km}$ from Kuching, the capital city of Sarawak (usually 1.5 hours by road). Less than ten years ago, Serikin was not well known except for the locals who knew Serikin as a border village, accessible to the Kalimantan border via small paths and rivers, locally called 'jalan tikus'. Literature on Serikin, except about the tourism promotion, is almost nil. The nearest town to Serikin is Bau, ten kilometers away, and Serian, a larger town, about $30 \mathrm{~km}$ away. The predominant community living in Serikin is the Bidayuh community, an ethnic group categorized under the Dayak group living in rural areas. The Bidayuhs grow paddy, pepper, maize, tapioca, pineapples and collect jungle produce. These subsistence farm and jungle produce are usually sold in local markets (indigenously known as tamu) and also for family consumption. The Bidayuh of Serikin share similar dialects with their kin at Jagoi Babang.

A World Bank Report in 2007 on cross-border trade in Central Asia noted that crossborder trade is defined as the flow of goods and services across international land borders within a reach of up to thirty kilometers, plays an important role in supporting the livelihood of border communities, and thereby, buttressing prosperity in central Asia. Furthermore, by strengthening commercial ties, promoting cultural understanding, and deepening community relationships (Putnam in DeFillippis, 2001), cross-border trade helps to nurture amicable relations between neighbours (World Bank, 2007:8). Likewise, the congregation of traders from both sides of the West Kalimantan and Sarawak border has transformed Serikin into a 'mall within the forest', as termed by the locals. This term fits Serikin, where varieties of consumer goods, ranging from textiles, dry food, pots and pans, electrical goods, toys, traditional medicine, furniture, rattan mats, jungle produce, vegetables, fruits, handicrafts, spices and many more, are sold at relatively cheaper prices than the market price in Kuching City. The cross-border trades had slightly reduced the market price, but it is sufficient enough to obtain better profits to put a price higher than their home countries (Titeca, 2009). Food stalls, foot reflexology kiosks, traditional medicine booths, and karaoke in the evening, are amongst some of the facilities and activities available, making the border market not only a place to buy and sell, but also a place to unwind, entertain and be entertained during the weekends. In the early afternoon on Sunday, the exodus of traders will begin, and by late evening, the Serikin bazaar becomes deserted and quiet, for the next four days at least. The local villagers usually go about their daily activities without much attention to the quiescence of the place, and come Friday, the hustle and bustle will start again when the bazaar livens up with people carrying out their trading activities.

A survey was conducted in the middle of 2009 on 51 traders at the Serikin border bazaar. These traders come mostly from West Kalimantan, e.g. Pontianak (57\%), with some traders from other small towns and villages, such as Sangau Ledo (14\%), Singkawang (4\%), and Selaus (3.9\%). There are only five local respondents from Serikin and Tebedu (Table 1). This small number reflects less participation of local traders as compared to Indonesian traders. 
Table 1

Respondents place of origin

\begin{tabular}{|c|c|c|c|c|}
\hline \multicolumn{3}{|l|}{ Place } & No & $\%$ \\
\hline \multicolumn{3}{|l|}{ Serikin \& Tebedu } & 5 & 10 \\
\hline \multicolumn{3}{|l|}{ West Kalimantan } & 46 & 90 \\
\hline & No & $\%$ & & \\
\hline Pontianak & 29 & 64 & & \\
\hline Sangau Ledo & 7 & 15 & & \\
\hline Singkawang & 2 & 4 & & \\
\hline Selaus & 2 & 4 & & \\
\hline Other small towns & 6 & 13 & & \\
\hline \multicolumn{3}{|l|}{ Total } & 51 & 100 \\
\hline
\end{tabular}

Out of the 51 respondents, $32(62.7 \%)$ are males and 19 are females. Similarly, a cross-border trade between Tanzania and its neighbouring countries is also dominated by men coming from towns at the border (Ackello-Ogutu \& Echessah, 1998). In terms of marital status, 41 (80.4\%) of the traders interviewed are married, while 9 (17.6\%) are single and one chose not to respond to this question. The survey found that a total of 15 respondents are involved in business as their main occupation, whereas 29 respondents (56.9\%) are subsistence farmers, with no other secure jobs (Table 2). Several respondents engage in the trading activities as part-time vocation, which means that they do not have other jobs apart from trading at Serikin. Majority of the Indonesian respondents also reported that they are involved in petty trading in their villages in West Kalimantan while they are trading at Serikin.

Table 2

Respondents background

\begin{tabular}{|l|c|c|}
\hline \multicolumn{1}{|c|}{ (i) Gender } & No & \% \\
\hline Male & 32 & 63 \\
\hline Female & 19 & 37 \\
\hline Total (ii) Marital Status & 51 & 100 \\
\hline Married & 41 & \\
\hline Single & 9 & 80 \\
\hline No respond Main occupation & 1 & 2 \\
\hline Total (iii) & 51 & 100 \\
\hline \multicolumn{1}{|c|}{} & 15 & \\
\hline Businessman & 29 & 29 \\
\hline Farmer & 7 & 14 \\
\hline Housewife & 51 & 100 \\
\hline Total & & \\
\hline
\end{tabular}


Because of its associations with marginality and the struggle for survival, the small scale traders are often assumed to be poorly educated (Alusala, 2010). But like traders in previous studies (see Peberdy, 2000; Peberdy and Crush 2001), generally the respondents at Serikin have fairly good education where $45.1 \%$ attended Upper Secondary School, 21.6\% completed primary school, and 11.8\% achieved lower Secondary school certificates and university respectively (Table 3 ). The frequency of their business activities ranges from twice a week among 25 respondents (49\%), while 18 respondents (35.3\%) carry out their business 7 days a week, in their village and on the weekends at Serikin. In terms of the distribution of types of sales, the figures show that 14 respondents (27.5\%) are selling textile which include clothings, batik sarongs, curtains and t-shirts plus apparels. The rest of the respondents are engaged in activities such as selling cooked food (9.8\%), vegetables and jungle produce (9.8\%), household furniture and rattan mats (5.9\%) (Table 4). Majority of the respondents $(84.3 \%$ ) run their own individual businesses whilst only 7 or $13.7 \%$ in the form of partnerships.

Table 3.

Education level of respondents

\begin{tabular}{|l|c|c|}
\hline Education level & No & $\%$ \\
\hline No Schooling & 5 & 9.7 \\
\hline Primary School & 11 & 21.6 \\
\hline Lower Secondary School & 6 & 11.8 \\
\hline Upper Secondary School & 23 & 45.1 \\
\hline University & 6 & 11.8 \\
\hline Total & 51 & 100 \\
\hline
\end{tabular}

Table 4

Type of goods sold

\begin{tabular}{|l|c|c|}
\hline Types of goods sold & No & \% \\
\hline Textile & 14 & 27.5 \\
\hline Cooked food & 5 & 9.8 \\
\hline Vegetables \& jungle produce & 5 & 9.8 \\
\hline Household furniture \& rattan mats & 3 & 5.9 \\
\hline Electrical goods & 2 & 3.9 \\
\hline Others & 22 & 43.1 \\
\hline Total & 51 & 100 \\
\hline
\end{tabular}

The early findings of this survey revealed that Indonesian traders chose to trade in Serikin because of their experience in running small businesses back home. The interest to extend their business at Serikin is inevitable due to the cultural familiar- 
ity and the use of common communication dialect. Desire to have extra income to supplement their household income, unemployment, lack of opportunities in development programs and low income from their small farms insufficient to subsist the household needs; are some of the oft-quoted reasons as to why they trade at Serikin. The border traders at South Africa and neighbouring countries are also mainly driven by income earning opportunities (Damon and Jeuring, 2009; Peberdy, 2000). Most of the respondents claimed that doing business at the Serikin bazaar is very satisfying. Almost all respondents chose Serikin bazaar as their business location because of the spaces provided which are relatively cheap, as well as easy access across borders using a Border Pass which is valid for a year. The Pass is obtained from the Indonesian government which facilitates easier mobility into the Sarawak border. Previous research shows that cross-border traders are encouraged by a safe location and low business, for example, in Zimbabwe (Muzvidziwa, 2001) and India (Taneja and Pohit, 2002). To the Indonesian traders in particular, the lucrative income obtained from trading activities at this border bazaar, with an average net profit of RM800 (USD250) per month, offers incentives for them and regard Serikin as their prospective source of income.

\section{Implication of the socio-economic dynamics}

Communities at the border village benefit from the booming business. Local nascent entrepreneurs construct makeshift stalls and rent them to the Indonesian traders for a minimal charge of between RM60-80 (USD15-20) per month. Serikin locals also take the opportunity to earn extra income from the weekend trading. They provide pay-parking spaces at their home compounds for urban tourists who drive in cars and come in buses. They also open up more restaurants and eateries to cater for the weekend shoppers, while private homes rented rooms to the Indonesian traders for a minimal fee of RM5.00 (USD1.50) per day. For storage of their trading goods, an additional fee of RM70 (USD20.00) is imposed on the Indonesian traders when they had to return to Kalimantan after the weekend bazaar. Toilets built by the local communities behind shops and houses are also charged for public use. When asked whether the growth of Serikin border town affect their lives, the communities tend to agree with the transformation that benefit them economically. They also agreed that despite the lack of intervention from the local council to assist in the construction of the bazaar (except to charge the traders RM5.00 for garbage fees by the council), the communities are able to participate and benefit from the businesses.

Interviews with local villagers and headmen reveals that the socio-economic conditions of the local communities had improved since Serikin grew into a border bazaar. The informal structures of the bazaar and the physical transformation at the site are clear manifestation of participation by the local communities and the Indonesian traders to prosper one another. Unless the local council intervenes in aspects such as physical regulation, structured fees and tax, the present growth of Serikin to sustain on its own and be self-reliant is assured. The spill effects of the trading by Kalimantan traders at Serikin bazaar has inevitably affect nearby village, for example, the Duyoh tamu located at Kampung Duyoh (Duyoh village). Stalls at this 
tamu are managed by village women where they sell handicrafts, pitcher plants, wild and rare orchids, fruits, vegetables and jungle produce. Inevitably, some of the produce sold at this tamu are obtained from the Serikin bazaar, a manifestation of the movement of goods at the lower circuit i.e. the village level vis-à-vis the border market.

Besides the business opportunity and economic factors, the Indonesian traders are motivated to come to Serikin because of the social networking. When asked on their participation at the Serikin bazaar, the traders earnestly claimed that they look forward coming to Serikin over the weekends to do business despite the enduring 8-12 hours journey by lorries and motorcycles from town to village at West Kalimantan. Their association with other traders from Indonesia and Malaysia are observed and maintained, thus cultivating social bond that is pertinent to sustain their trade involvement in a foreign bazaar. The market provides a point for them to meet friends and kinsfolk, exchange ideas and stories from their respective villages and sharing mutual interests. Such phenomenon of the emergence of border bazaars becoming focal points of interaction and exchanges had been accentuated by other studies in other countries (Nair and White, 1999; Greve and Salaff, 2003; Papa and Papa, 2006). As in the case of the Sarawak-West Kalimantan border, the social bonding had further encourage them to come to Serikin, not just for the business, but also for the emotional attachment they have established over time. Wealth, in the form of money, social, emotional and psychological bonds, are the incentives these traders brave the long and tedious journey to Serikin every weekend. Serikin is seen as giving them the opportunity towards the betterment of their lives, economically, and socially. Most importantly, the acceptance of the local communities in Serikin toward the petty traders from the West Kalimantan has been perceived as the social endearment and licit social space for the latter to trade in peace.

Indonesian traders from West Kalimantan, especially from the Jagoi Babang village, and the local people of Serikin, Sarawak, share one common narrative of history, that is, they originated from the mountain called Jagoi Hill. This mountain was where their ancestors used to live together. Then over the years some of the villages decided to descend to live at the base of the hills. When the nation of Indonesia and Malaysia (Sarawak) came into being, respectively in 1947 and 1963, the Jagois found themselves separated, one segment of the population belonging to Indonesia, called Jagoi Babang, and the other segment of population belonging to Malaysia, called Jagoi Serikin.

The socio-economic dynamics taking place at both the Sarawak-Kalimantan border has indeed extended beyond cultural realms as argued by Bourdieu (in DeFillippis, 2001). The opening of petty trading post and economic exchanges at Serikin has helped generate income for traders from West Kalimantan and local people of Serikin in Sarawak, thus strengthening the local ties and expanding better opportunities for both sides of the communities to sustain their livelihood and social integration at the margins of development. This dynamics is traced to historical and cultural bonding which can be summarised as follows: 
Figure 1

Re-Linking Border Communities

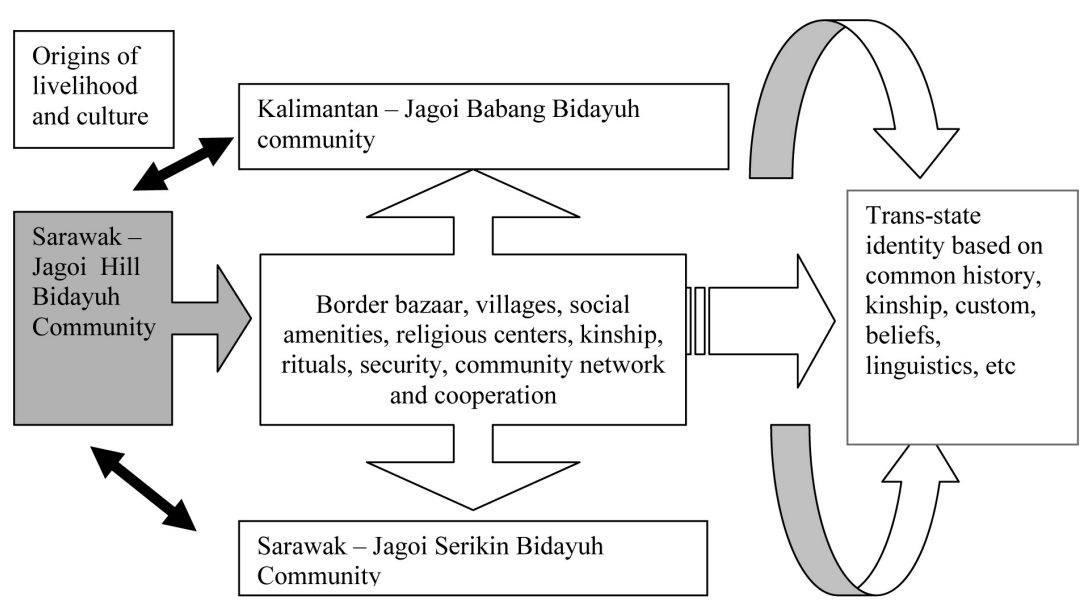

\section{Conclusion}

Border communities are not isolated from the dynamics of market and the multifacets of petty capitalism in its lowest form, which are integrated and extended to other (social) forms. Communities at the border, in this case communities from both Sarawak and West Kalimantan, developed and transformed Serikin into a bustling bazaar where people from both sides of the physical boundary are able to participate actively in businesses, and extending the social bonding. With minimal intervention from the state, it is observed that the lack of formal structure to regulate the economic and social interaction at the Serikin bazaar is able to pull traders from West Kalimantan to take opportunities of the market transaction at this border village. Private ownership of spaces here has enabled individuals - house owners and landowners to utilize their properties as economic resources to facilitate the market activities at Serikin. Affinities between border communities based on their past history, kinship, beliefs, cultural symbols and dialect, are reestablished and reinforced, and these will continue to grow in tandem with the market dynamics. The social characterization of such dynamics is manifested in new forms and new expectations which have been sustained over the decades. Border markets may become the future catalyst for communities here to examine and relook into their social identities and economic aspirations. Being physically and socially distant from the center of power (Jakarta), Serikin market manifests a 'trans-state identity' for the petty traders from West Kalimantan. 


\section{References}

1. Ackello-Ogutu, C. A and Echessah, P. N (1998). Unrecorded cross-border trade between Tanzania and Neighbours Implication for food security. Technical paper, 89: 1-99.

2. Gay, L. R and Airasian, P. W (2000). Educational research: Competencies for analysis and application. Prentice Hall.

3. Alusala, N. (2010). Informal cross-border trade and arms smuggling along the Uganda-Rwanda border. African Security Review, 19 (3): 15-26.

4. Amster, M. H and Lindquist, J. (2005). Frontiers, sovereignty and marital tactics: Comparisons from the Borneo Highlands and the Indonesia-Malaysia-Singapore Growth Triangle. The Asia Pacific Journal of Anthropology, 6 (1): 1-17.

5. Bala, P (2001). Interethnic Ties: The Kelabit and LunBerian in the Kelabit-Kerayan Highlands. Borneo Research Bulletin, 32: 103-111.

6. Bariyah, N.; Lau, E. and Mansor, S. A. (2012). Long run sustainability of SarawakWest Kalimantan cross border trade flows. The Journal of Developing Areas, 46 (1): 165-181.

7. Baud, M. and Schendel, W. V. (1997). Towards a comparative history of borderlands. Journal of World History, 8: 211-242.

8. Cook, I, J. and Crang, M. (1995). Doing Ethnographies: issue 58 of concepts and techniques in modern geography. 58 Institute of British Geographers.

9. Crain, J. (1981). The LunDayeh of Sabah, East Malaysia: Aspects of Marriages and Social Exchange. Ph.D. dissertation. Michigan: Cornell University (Xerox copy from University Microfilms International, Ann Arbor.

10. Damon, M., and Jeuring, K. (2009). Informal cross-border trade as an instrument alleviating poverty. Open Society Initiative for Southern Africa: 114-118.

11. Defilippis, J. (2001). The myth of social capital in community development. Housing policy debate, 12 (4): 781-917.

12. Eilenberg, M. and Wadley, R. L. (2009). April. Borderland livelihood strategies: The socio-economic significance of ethnicity in cross-border labour migration, West Kalimantan, Indonesia. Asia Pacific Viewpoint, 50 (1): 58-73.

13. Eilenberg, M. (2009). Intersecting spheres of 'legality' and 'illegality': A case of cross-border labour migration in West Kalimantan, Indonesia. Paper presented at the Workshop on Labour Migration and Trafficking: Policy Making at the Border, co-organised by CAPSTRANS, University of Wollongong, Australia and Institute of Ethnic Studies (KITA), UKM, on 1-3 August, at UKM Bangi.

14. Eilenberg, M. (2012). Territorial soveriginty and trafficking in the Malaysia-Indonesia borderlands, in: Ford, M., Lyons, L. \& van Schendel, W. (Eds.). Labour migration and human trafficking in Southeast Asia: Critical perspectives. New York: Routledge.

15. Greve, A. and Salaff, J. W. (2003). Social networks and entrepreneurship. Research paper. University of Toronto.

16. Horstmann, A and Nishii. R. (2002). Introduction. Panel on Border Identities at the Southern Thailand/Northern Malaysian Frontier. The First Inter-Dialogue Conference on Southern Thailand: Current Transformations from a People's Perspective. 13-15 Jun 2002. (http://www.unimuenster.de/Ethnologie/South_Thai/ resource/PAHorstmann Introduction.pdf). (6. Mei 2008). 
17. Ishikawa, N (2010). Between Frontiers: Nation and identity in a Southeast Asian borderland. Ohio: Ohio University Press.

18. Ketut, A.; Langub, J. and Chew, D. (2004). Border of kinship and ethnicity: Cross border relationships between the Kelalan valley, Sarawak, and the Bawan valley, East Kalimantan. Borneo Research Bulettin, 35: 144-179.

19. Koji, M. (2002). Socio-cultural Dynamics in Border Societies: Introduction to the Symposium. Keynote address delivered at the International Symposium: Dynamics of Border Societies in Southeast Asia. Research Institute for Foreign Languages and Cultures of Asia and Africa, Tokyo University of Foreign Studies, Japan.

20. Noeb, L. M. (2006). Bidayuh society and traditions, in: Hood Salleh (Ed.). Peoples and Traditions vol 12. Kuala Lumpur: Editions Didier Millet.

21. Martinez, O. J. (1994). Border people: Life and society in the US-Mexico borderlands. Tucson: University of Arizona Press.

22. Muzvidziwa, V. (2001). Zimbabwe's cross-border women traders: Multiple identities and responses to new challenges. Journal of Contemporary African Studies, 19 (1): 67-80.

23. Nair, S. and White, S. (1993). The development communication process: a reconceptualization, in: Dlm. Nair, S. \& White, S. (Eds). Perspective on development communication. New Delhi: Sage Publication.

24. Papa, M. J., Singhal, A. and Papa, W. H. (2006). Organizing for social change. New Delhi: Sage Publication.

25. Peberdy, S. and Crush, J (2001). Invisible trade. Invisible travelers: The Maputo Corridor Spatial Development initiative and informal cross-border trading. South African Geographic Journal, 83 (2): 115-123.

26. Peberdy, S. (2000). Mobile entrepreneurship: Informal sector cross-border trade and street trade in South Africa. Development Southern Africa, 17 (2): 201-219.

27. Taneja, N. and Pohit, S. (2002). Characteristics of India" Informal and Formal Trading with Nepal: A Comparative Analysis. Indian Economic Review, 37 (1): 69-89.

28. Tirtosudarmo, R. (2006). In the margin of a borderland: The Florenese community between Nunukan and Tawau. Asian anthropologies, 4: 135-154.

29. Titeca, K. (2009). The Changing Cross-Border Trade Dynamics between northwestern Uganda, North-eastern Congo and Southern Sudan. Working Paper no. 63. Institute of Development Policy and Management, University of Antwerp.

30. Wadley-Reed L. (1998). The road to change in the Kapuas Hulu Borderlands: Jalan-Lintas Utara. Borneo Research Bulletin, 29: 71-94.

31. World Bank (2007). Cross-Border Trade within the Central Asia Regional Economic Cooperation. August 20. (http://www.carecprogram.org/uploads/docs/ Cross-Border-Trade-CAREC.pdf).

32. Yokoyama, S. and Sakurai, T. (2006). Potential of social for community development. Tokyo: Asian Productivity Organization (APO). 
Prethodno priopćenje

Junaenah Sulehan

Filozofski fakultet; Centar za društvena, razvojna i okolišna istraživanja; Fakultet Kebangsaan; Malezija e-mail: june@ukm.my

Noor Rahamah Abu Bakar

Filozofski fakultet; Centar za društvena, razvojna i okolišna istraživanja; Fakultet Kebangsaan; Malezija e-mail:rahamah@ukm.my

\section{Abd Hair Awang}

Filozofski fakultet; Centar za društvena, razvojna i okolišna istraživanja; Fakultet Kebangsaan; Malezija e-mail: hair@ukm.my

Mohd Yusof Abdullah

Filozofski fakultet; Centar za medije i komunikacijska istraživanja; Fakultet Kebangsaan; Malezija e-mail: myusof@ukm.my

Ong Puay Liu Institut za etnička istraživanja; Fakultet Kebangsaan; Malezija

e-mail:puayliu@yahoo.com

\section{Razvoj na marginama: egzistencija i održivost zajednica na malezijsko- indonezijskoj granici}

\section{Sažetak}

Male zajednice koje žive na marginama razvoja općenito se suočavaju s brojnim problemima i izazovima. Premda je opstojnost njihova glavna briga, integracija u glavne razvojne tokove paradoksalno ostaje dalek i nerješiv problem. Stoga ovaj članak ima tri cilja. Prvo, u njemu se bavimo socio-ekonomskom dinamikom Sarawak-Kalimantan pograničnih zajednica čija sela ostaju izvan glavnih tokova razvoja. Nedavno su sela i manji gradovi uz ovu granicu privukli pažnju medija, političara, istraživača. Bio je to rezultat medijskog zanimanja za malezijskoindonezijske granične prepirke i kulturne prijepore. To se kasnije proširilo na pitanja o nacionalnoj sigurnosti i ekonomskim interesima obiju zemalja. Međutim, nepovoljne socio-ekonomske okolnosti ovih pograničnih zajednica rijetko su kada jasno artikulirane. Druga svrha članka je ukazati na probleme opstojnosti i održivosti ovih pograničnih zajednica, osobito zajednice Bidayah iz Serikina (Sarawak) i zajednice JagoiBabang (Zapadni Kalimantan). Studije slučaja, provedene 2009. i 2010., posebno su se bavile učešćem seljaka u socio-ekonomskim pitanjima unutar graničnih područja i posljedičnim utjecajem na njihovu egzistenciju. I, napokon, razmatrajući moguće teorijsko objašnjenje ovoga jedinstvenoga socijalnog fenomena koji se odvija na margini razvoja u Maleziji, u članku se propituju duboko ukorijenjene kulturne i društvene veze koje omogućuju održavanje tradicije ekonomske razmjene između zajednica s obje strane granice.

Ključne riječi: razvoj zajednice, opstojnost, održivost, pogranične zajednice, socijalna dinamika. 